\title{
Changes in Body Weight, Milk Production, Food and Water Consumptions and Vaginal Smears in Rats during Prolonged Lactation
}

\author{
Hiroshi TOMOGANE, Katuaki ÔTA, Haruko UNNO, \\ AND AKIRA YOKOYAMA \\ Faculty of Agriculture, Nagoya University, \\ Chikusa-ku, Nagoya 464
}

\begin{abstract}
Synopsis
Concurrent observations were made in the rat on the changes in the milk production, body and organ weight, food and water consumptions and in the ovarian function in two separate series of experiments in which the period of lactation was prolonged to 60 and 45 days, respectively, by replacing suckling pups by younger ones.

In most of the variables examined, marked changes occurred between day 20 and 30 of lactation, that is, at the stage corresponding to the end of the normal lactation period. Milk production rate during prolonged lactation expressed by daily gain in weight of litters decreased to $60 \%$ of the level before day 20 , and was associated with a great reduction of nucleic acid contents of the mammary gland. Definite decreases in weights of the anterior pituitary and the adrenal glands were observed. The food intake remained constant from day 15 of lactation onwards, therefore, the feed efficiency for milk production declined gradually during the period of normal lactation remaining at a low level thereafter. After the first recurrence of vaginal estrus which also occurred between day 20 and 30, the replacement of litters was followed by the appearance of estrus, whereas replacement before day 15 did not affect the ovarian function. In addition to these changes, a depressing effect of estrus on the milk production was observed.
\end{abstract}

In a previous paper, we reported changes in the ovarian function in lactating rats in which lactation was prolonged for a maximum of 60 days by replacing suckling pups periodically (Tomogane et al., 1976). Throughout the entire period of lactation we also recorded vaginal smears, body weight of the mother, gain in litter weight and weights of various endocrine organs at autopsy.

To obtain more information about prolonged lactation, we performed recently another series of experiment in which effects of the suckling stimulus on the secretion of prolactin and corticoids were investigated in prolonged lactating rats. In this series, body and organ weights of the mother, daily gain in litter weight and vaginal smears were also recorded throughout 45 days of prolonged lactation. Food and water comsumptions of the mother, in addition, were measured daily in some animals of this series. The results obtained in two series were in good agreement, and, therefore, we are combining them.

Part of the results of the hormonal secretion obtained in the second series has been reported as a short communication (Ôta et al., 1974). 


\section{Materials and Methods}

Primiparous albino rats of Wistar-Nagoya (200 $250 \mathrm{~g}$ at parturition) and Wistar-Imamichi (250-310 g) strains were used in Series 1 and 2, respectively. They were maintained in a temperature- $\left(24 \pm 2^{\circ} \mathrm{C}\right)$ and light- (lights on at 05.00 and off at $19.00 \mathrm{hr}$ ) controlled animal room. Stock diet (CLEA CA-1 pellet, Nihon CLEA Co., Ltd., Tokyo) and water were given ad libitum. Animals were housed in individual wooden cages from the mid-pregnancy. Cages specially made for measurement of food and water intakes were used for some rats in Series 2. The day on which the newborn young were first found in the morning was defined as day 0 of lactation. Within 2 days of birth the number of pups in a litter was adjusted to eight, and was maintained at this number throughout the whole experimental period. Mothers and litters were weighed separately every morning (09.00-10.00 hr). Vaginal smears were also examined daily.

Series 1. Lactation was prolonged up to a maximum of 60 days by replacing litters. Renewal of litters was first performed on day 10,14 or $17-18$ of lactation and repeated thereafter at intervals of 5-13 days, mainly of 9 days. Healthy pups of 4-6 days old were used for the fostering. Mothers were killed by exsanguination on appropriate days of normal and prolonged lactation after collection of the ovarian vein blood had been completed (Tomogane et al., 1976). Anterior and posterior lobes of the pituitary gland, ovaries, uteri, and adrenal glands were quickly removed and weighed at the time of autopsy. Six posterior mammary glands were also removed, weighed after dissecting off tissues other than mammary parenchyma and stored deep-frozen. In some of the prolonged lactating rat, the nucleic acid content of the mammary glands was measured by the method of Schmidt-Thannhauser-Schneider (Schneider, 1946), using diphenylamine reaction (Dische \& Schwartz, 1937) and orcinol reaction (Ceriotti, 1955) for colorimetric determination of DNA and RNA, respectively.

Series 2. Replacement of litters was carried out on day 15 of lactation and repeated at intervals of 10 days thereafter. Foster pups used were 5-6 days old and the weight of the foster litter (8 pups) exceeded $80 \mathrm{~g}$ on day 5 in all cases. Since the experiment was designed originally to investigate the effect of suckling on the secretion of prolactin and corticoids, timed suckling for $30 \mathrm{~min}$ after separating the pups from the mothers for $10 \mathrm{hr}$ was performed on days 15, 25, 35 and 45 of lactation (Ôta et al., 1974), and mothers were guillotined just before and after the suckling period. At autopsy, the above mentioned organs were removed and weighed.

In eleven rats in which lactation was prolonged up to 45 days, food and water intakes were measured daily between 10.00 and $10.30 \mathrm{hr}$ throughout the experimental period. Amounts of food and water consumed by each animal during the preceding 24-hr period were regarded as the food and water intakes of the day, respectively. Multiple range test of Kramer (1956) was used for statistical analysis.

\section{Results}

Results of the body weight and food and water intakes of mother rat and of the gain in litter weight described here are obtained from 9 and 11 rats in Series 1 and 2 , respectively.

Changes in body weight of mother rats during normal and prolonged lactation (Fig. 1a).

In either Series 1 or 2 , the body weight of mother rats increased steeply up to the middle stage of normal lactation (days 10-15), but then decreased until days 2125 , i. e. to the time corresponding to the end of normal lactation, thereafter increasing

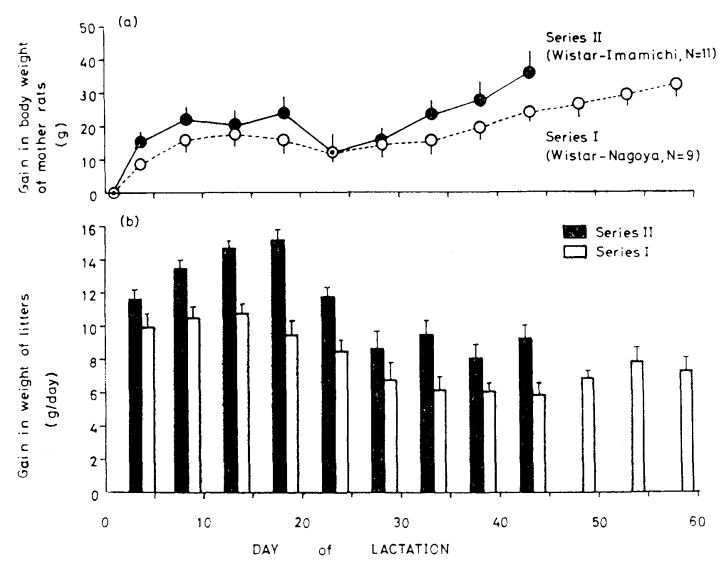

Fig. 1. Changes in body weight of mother rats (a), and in daily gain in weight of litters (b) during normal and prolonged lactation. Data were summarized every 5 days (see Text). Vertical lines indicate \pm S.E.M. $\mathrm{N}$ : Number of animals used. 
steadily throughout the period of prolonged lactation.

Changes in daily gain in litter weight during normal and prolonged lactation (Fig. 1b).

The gain in litter weight remained fairly constant or gradually increased during the first 15 or 20 days, and decreased during the following 10 days. The gain observed around day 30 was about $60 \%$ of that noted before day 20. This low level of gain in litter weight was generally maintained during the remaining period of prolonged lactation, but there was a slight increase in gain after day 45 in Series 1.

Recurrence of estrous cycle and effect of estrus on milk production

Results used for analysis in this and the next section were obtained from 19 rats of Series 1 (12 rats lactating for more than 50 days and 7 rats for 35-44 days) and from 17 rats of Series 2 (11, 4 and 2 rats lactating for 45,35 and 25 days, respectively). The definition of the terms used here for analysis of the vaginal smear record was the same as that used in the previous paper (Tomogane et al., 1976). The lenghth of the first diestrous period was $22.9 \pm 0.8$ (mean \pm S. E. M.) days in Series 2 being about 1 day longer than that in Series 1 reported previously (Tomogane et al., 1976). A long diestrous period lasting more than 7 days was observed at least once in all animals examined in Series 2; a diestrous period shorter than 3 days appeared in only $30 \%(8 / 27)$ of occasions observed. These results were essentially the same as those obtained in Series 1. One out of 11 rats lactating for 45 days showed neither proestrous nor estrous smears throughout the experimental period. To investigate a suspicion arising during the analysis that the abrupt depression of the daily gain in litter weight was accompanied with the appearance of estrogenic (proestrous and/or estrous) smears, changes in the gain were re-arranged in reference to the date of appearance of estrogenic smears instead of to the day of lactation (Fig. 2). A significant decrease in milk yield occurred on the day before (Series $1, \mathrm{P}<0.01$ ) or on which the estrogenic smear appeared (Series 2, $\mathrm{P}<0.01$ ) and the yield had not returned after 2 days to the level of the preceding 2 days.

Effects of replacement of litters on the vaginal smear and on the daily gain in litter weight in normal and prolonged lactating rats

In Series 2, a considerable number of rats showed estrogenic vaginal smears on
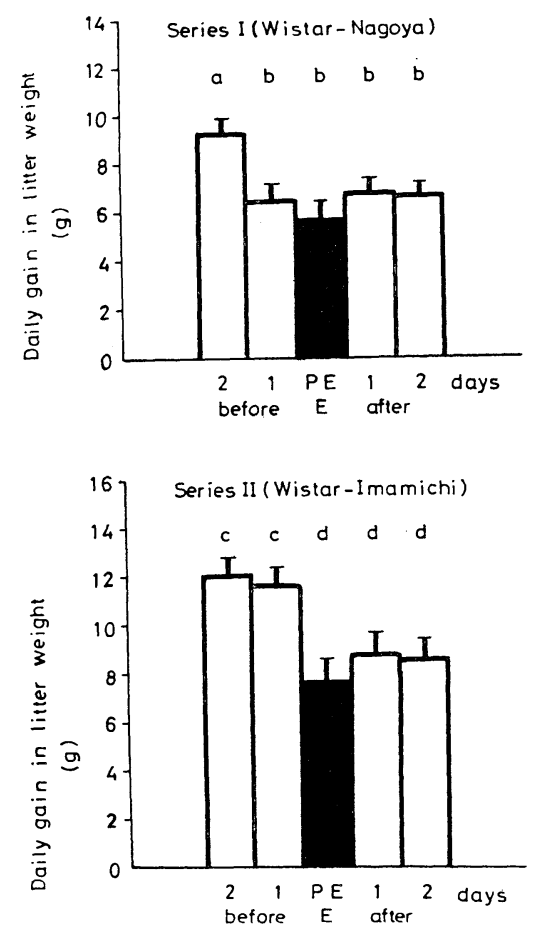

Fig. 2. Changes in the daily litter weight gain around the day on which estrous or proestrous smears appeared. Numbers of observations in Series 1 and 2 are 53 and 28, respectively. Vertical lines indicate + S.E.M. Differences between bars having the same letter are not statistically significant at $5 \%$ level. 
days $26-28$ and on days $36-38$ of lactation regardless of the date of appearance of previous estrogenic smears. Therefore, the interval between the litter replacement and appearance of the estrogenic smear was examined over the period of normal and prolonged lactation in both Series 1 and 2 (Table 1). When the replacement of litters was performed after day 17 of lactation, proestrous or estrous smears appeared within 3 days after the replacement in more than half of the occasions observed (40/78 in Series 1 and $17 / 26$ in Series 2). When the litters were replaced before day 15 , on the other hand, the interval was more than 4 days in all rats examined in Series 1 and in 15 out of 17 in Series 2.

Changes in the litter weight gain were examined around the time of litter replacement, in order to test the possibility that the litter replacement may affect the change in daily gain in litter weight (Fig. 3). The weight gain for 3 days following the replacement of litters was not different from or somewhat larger than that obtained for 2 days before the replacement, when the replacement was performed before day 15 of lactation (means of 12 and 17 occasions in Series 1 and 2, respectively). Replacement of litters after day 17 of lactation (78 and 26 occasions) also caused a slight increase in the weight gain of litters on the day following the replacement, but the weight gain decreased on the 2 nd or 3 rd day after the replacement.
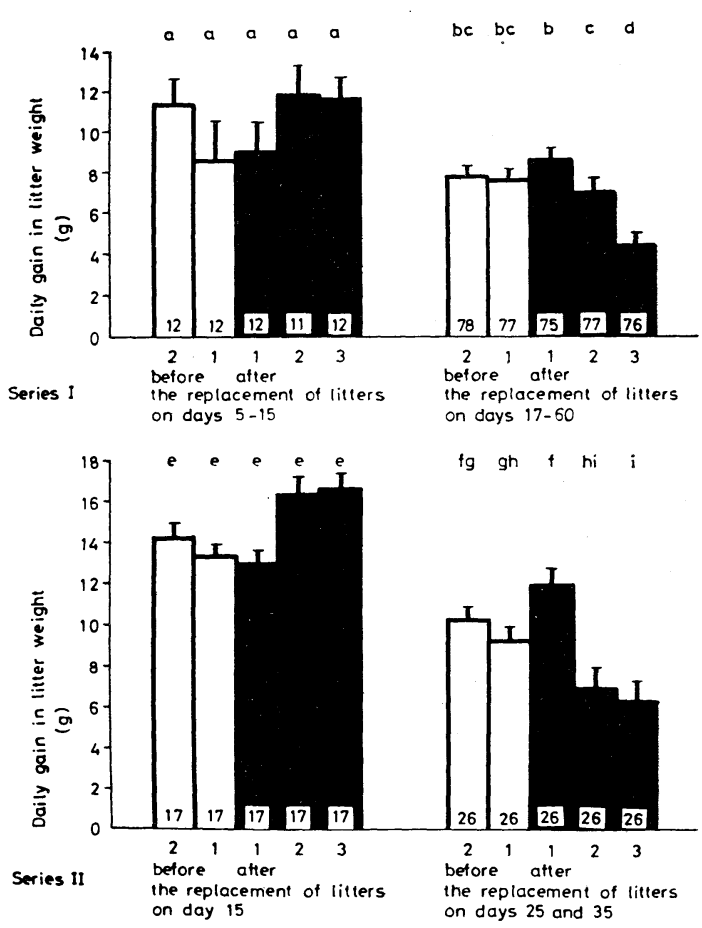

Fig. 3. Daily gain in litter weight of 2 days preceding and 3 days following the replacement of litters in normal and prolonged lactating rats. Numbers of observations are shown at the bottom of the bars. Vertical lines indicate+S.E.M. Differences between bars having the same letter are not statistically significant at 5\% level.

Table 1. Distribution of the interval between the replacement of litters and the appearance of estrous or proestrous smear in normal and prolonged lactating rats

\begin{tabular}{|c|c|c|c|c|c|c|c|c|c|c|c|c|c|}
\hline \multirow{2}{*}{\multicolumn{2}{|c|}{$\begin{array}{l}\text { Statge of lactation at the } \\
\text { replacement of litters }\end{array}$}} & \multicolumn{11}{|c|}{ Intervals (days) } & \multirow{2}{*}{$\begin{array}{c}\text { Total No } \\
\text { of obser- } \\
\text { vations }\end{array}$} \\
\hline & & 1 & 2 & 3 & 4 & 5 & 6 & 7 & 8 & 9 & 10 & $\begin{array}{c}\text { Not* }^{*} \\
\text { appeared }\end{array}$ & \\
\hline \multicolumn{14}{|c|}{ Series 1 (Wistar-Nagoya) } \\
\hline \multirow[t]{2}{*}{ Normal } & day $10-14$ & & & & 2 & & 1 & & & & & 9 & 12 \\
\hline & day $17-20$ & 1 & 3 & 2 & 1 & & 1 & 1 & & & & 3 & 12 \\
\hline Prolonged & day $21-60$ & 7 & 22 & 5 & 1 & 3 & 1 & 2 & 2 & 2 & 1 & 20 & 66 \\
\hline \multicolumn{14}{|c|}{ Series 2 (Wistar-Imamichi) } \\
\hline Normal & day 15 & & 1 & 1 & & & 1 & 3 & 2 & 2 & & 7 & 17 \\
\hline Prolonged & day 25 or 35 & 6 & 8 & 3 & & & & & & & & 9 & 26 \\
\hline
\end{tabular}

* Neither PE nor E smear was observed during the period between the replacement of litters. 
Changes in food and water intakes of mother rats during normal and prolonged lactation (Series 2)

Changes in daily food and water intakes of mother rats and in feed efficiency for milk production throughout the lactation period in Series 2 are shown in Fig. 4. Food intake increased during the early stage of lactation and reached a plateau on days 11-15 of lactation. The intake remained constant or slightly decreased thereafter. The intake of water followed a similar pattern to food intake during the period of normal lactation and it declined markedly between days 26 and 30 .

The feed efficiency was arbitrarily calculated by dividing the daily gain in litter weight by the food intake of the mother on the same day. The values obtained decreased steadily until day 25 of lactation and remained at a low level thereafter.

Nucleic acid content of the mammary gland and weights of various organs of rats killed at different stages of normal and prolonged lactation

Results of determination of the nucleic acid contents of the mammary glands of animals in Series 1 are summarized in Table 2. Contents of DNA and RNA and RNA/DNA ratio in the mammary gland were markedly reduced as the period of lactation was prolonged. There were no significant differences in the contents and the ratio between two stages of prolonged lactation. The weight of the anterior lobe of the pituitary gland at the stage of days 21-35 of lactation was smaller than that
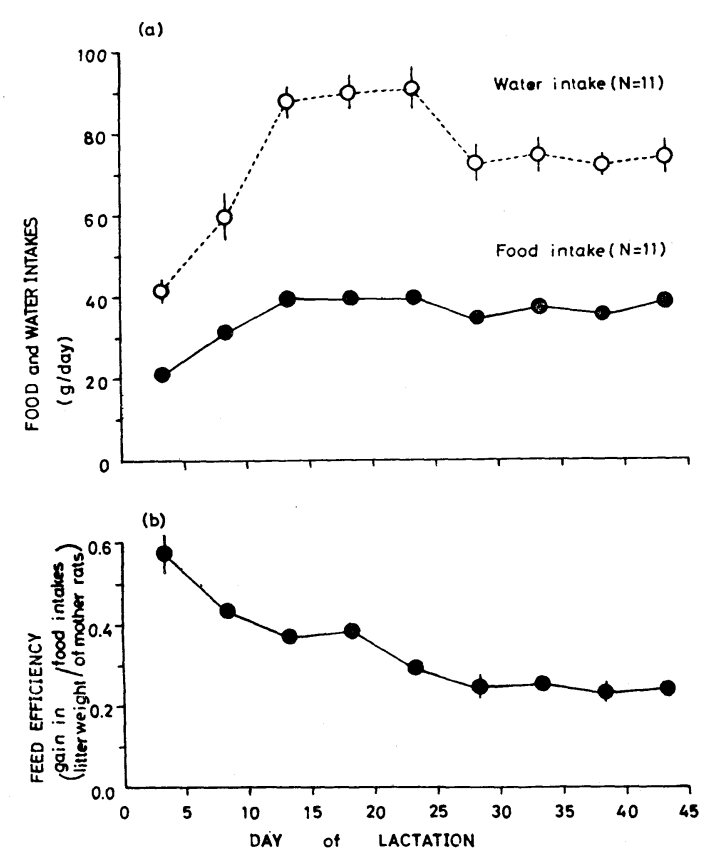

Fig. 4. Changes in food and water intakes (a), and feed efficiency (b) during normal and prolonged lactation. Vertical lines indicate \pm S.E.M. Data were summarized every 5 days. $\mathrm{N}$ : Number of observations.

Table 2. Nucleic acid contents of mammary glands in rats during normal and prolonged lactation

\begin{tabular}{lcccccc}
\hline \hline Lactation & $\begin{array}{c}\text { Time of } \\
\text { autopsy } \\
\text { (day of } \\
\text { lactation) }\end{array}$ & $\begin{array}{c}\text { No. of } \\
\text { rats } \\
\text { used }\end{array}$ & $\begin{array}{c}\text { Weight of } \\
\text { 6 posterior } \\
\text { mammary } \\
\text { glands }(\mathrm{g})\end{array}$ & $\begin{array}{c}\text { DNA } \\
(\mathrm{mg})^{* *}\end{array}$ & $\begin{array}{c}\text { RNA } \\
(\mathrm{mg})^{* *}\end{array}$ & RNA/DNA \\
\hline Normal $^{*}$ & 10 & 4 & $6.99 \pm 0.42^{\dagger}$ & $23.3 \pm 2.7$ & $54.6 \pm 6.5$ & $2.35 \pm 0.13$ \\
Prolonged & 15 & 4 & $8.01 \pm 0.23$ & $28.6 \pm 0.6$ & $81.1 \pm 3.9$ & $2.86 \pm 0.20$ \\
& $36-44$ & 5 & $5.95 \pm 0.41$ & $17.8 \pm 2.6$ & $26.7 \pm 4.7$ & $1.47 \pm 0.08$ \\
& $51-60$ & 9 & $8.31 \pm 0.37$ & $17.0 \pm 1.1$ & $30.0 \pm 2.9$ & $1.74 \pm 0.13$ \\
& Total & 14 & $7.47 \pm 0.27$ & $17.2 \pm 1.1$ & $28.8 \mp 2.5$ & $1.64 \pm 0.09$ \\
\hline
\end{tabular}

* Data were cited from Yokoi (1967) for comparison. The values were obtained in our laboratory using animals of the same strain and the same method of determination of nucleic acids as those used in the present experiment.

** Nucleic acid content was expressed in terms of $\mathrm{mg}$ in 6 posterior mammary glands.

$\uparrow$ Mean \pm S.E.M. 
Table 3. Weights of various organs of mother rats killed at different stages of normal and prolonged lactation

\begin{tabular}{|c|c|c|c|c|c|}
\hline \multirow{2}{*}{$\begin{array}{l}\text { Time of } \\
\text { autopsy } \\
\text { (day of } \\
\text { lactation) }\end{array}$} & \multirow[b]{2}{*}{$\begin{array}{l}\text { No. of } \\
\text { rats } \\
\text { used }\end{array}$} & \multicolumn{4}{|c|}{ Weight of organs } \\
\hline & & $\begin{array}{l}\text { Anterior } \\
\text { pituitary } \\
\text { gland (mg) }\end{array}$ & $\begin{array}{l}\text { Ovary } \\
(\mathrm{mg})\end{array}$ & $\begin{array}{l}\text { Uterus } \\
(\mathrm{mg})\end{array}$ & $\begin{array}{l}\text { Adrenal } \\
\text { gland } \\
\text { (mg) }\end{array}$ \\
\hline & & & Series 1 & & \\
\hline $1-10$ & 9 & $7.9 \pm 0.4 * a b$ & $70.8 \pm 3.8 \mathrm{c}$ & $552.2 \pm 138.3^{\circ} \mathrm{e}$ & $70.1 \pm 6.3 g$ \\
\hline $11-20$ & 11 & $7.9 \pm 0.1^{\circ} \mathrm{ab}$ & $64.3 \pm 1.6 \mathrm{~cd}$ & $190.4 \pm 24.4 f$ & $68.9 \pm 3.2 \mathrm{~g}$ \\
\hline $21-25$ & 11 & $7.2 \pm 0.4 \mathrm{ab}$ & $62.4 \pm 2.6 \mathrm{~cd}$ & $219.2 \pm 20.2 f$ & $59.7 \pm 1.9 \mathrm{~h}$ \\
\hline $26-30$ & 11 & $7.3 \pm 0.3 \mathrm{ab}$ & $60.9 \pm 2.5 \mathrm{~d}$ & $201.2 \pm 9.5 f$ & $53.6 \pm 2.3 \mathrm{~h}$ \\
\hline $31-35$ & 9 & $7.0 \pm 0.3^{\circ} \mathrm{b}$ & $63.8 \pm 1.5 \mathrm{~cd}$ & $224.6 \pm 22.3 f$ & $55.2 \pm 2.9 \mathrm{~h}$ \\
\hline $36-45$ & 11 & $8.1 \pm 0.3^{\circ} \mathrm{a}$ & $69.2 \pm 4.5 \mathrm{~cd}$ & $260.2 \pm 22.0^{\circ} \mathrm{f}$ & $55.3 \pm 2.2 \mathrm{~h}$ \\
\hline $51-60$ & 10 & $8.0 \pm 0.4 \mathrm{ab}$ & $63.4 \pm 2.9 \mathrm{~cd}$ & $223.1 \pm 17.3 f$ & $55.1 \pm 2.8 \mathrm{~h}$ \\
\hline & & & Series $2 * *$ & & \\
\hline 15 & 10 & $10.0 \pm 0.2 \mathrm{a}$ & $62.9 \pm 1.6 \mathrm{~d}$ & $172.1 \pm 7.2 \mathrm{e}$ & $74.9 \pm 1.8 f$ \\
\hline 25 & 10 & $7.9 \pm 0.2 b$ & $66.2 \pm 2.7 \mathrm{~d}$ & $214.4 \pm 15.7 \mathrm{e}$ & $72.8 \pm 2.2 \mathrm{fh}$ \\
\hline 35 & 10 & $8.7 \pm 0.4^{\circ} \mathrm{c}$ & $72.1 \pm 3.1 \mathrm{~d}$ & $179.5 \pm 6.9 \mathrm{e}$ & $59.8 \pm 3.4 \mathrm{~g}$ \\
\hline 45 & 11 & $9.8 \pm 0.3 \mathrm{a}$ & $69.4 \pm 4.3 \mathrm{~d}$ & $170.5 \pm 8.9^{\circ} \mathrm{e}$ & $66.3 \pm 3.0 \mathrm{gh}$ \\
\hline
\end{tabular}

* Mean \pm S.E.M.

** Timed suckling for 30 min was performed after separation of pups from their mothers for $10 \mathrm{hr}$. Mothers were killed just after the separating period without suckling or just after the suckling period. Data of these two groups were combined.

- Weighing of the organ was missed in one rat.

Differences between the means having the same superscript are not statistically significant at $5 \%$ level.

at other stages (Table 3 ). The weight of the adrenal gland was large at the beginning of lactation and declined progressively when lactation advanced in both series of the experiment. In Series 1, the adrenal weight decreased significantly between days 20 and 25 of lactation, and from day 25 onwards it remained constant up to day 60 . The decrease in weight of the adrenal gland also occured after day 25 of lactation in Series 2.

\section{Discussion}

Results of the present experiment are in good agreement with those of previous workers (Nicoll \& Meites, 1959; Kurz, 1967; Thatcher \& Tucker, 1968, 1970 a, b, c; Lorscheider \& Mears, 1973) in demonstrating a definite decline of lactational performance during prolonged lactation in the rat.
Insufficiency of hormones required for the maintenance of lactation seems to be a direct cause of the decreased milk production in prolonged lactation as suggested by the previous workers (Kurz, 1967; Thatcher \& Tucker, 1968, $1970 \mathrm{a}, \mathrm{b}, \mathrm{c}$; and Lorscheider \& Mears, 1973). However, the mechanism or the factors causing these hormonal changes have yet to be clarified. It is noteworthy, from this point of view, that the coincidence of the abrupt depression of either the daily gain in litter weight or weights of the adrenal and the pituitary glands with the first recurrence of the vaginal estrus was observed between days 20 and 30 of lactation. Inhibitory effect of estrus on the milk production in prolonged lactating rats was clearly demonstrated in the present experiment, although Bruce (1961) could not find the effect. It is suggestive that the changes observed in the present study are very similar to those caused by estrogen treatment in normal 
lactating rats. Yokoi (1967) found that the administration of estrogen caused decreases in weight of the adrenal gland and feed efficiency for milk production as well as of milk yield and of the mother's body weight (See also Yokoyama et al., 1968). Therefore, the possible participation of the change in gonadal function occurring at the end of the normal lactation period should be taken into consideration as one of the factors triggering the change in hormonal secretion and in lactational performance in prolonged lactating rats.

The replacement of litters performed in the present study did not affect the maintenance of lactation by itself. The daily gain in litter weight did not change, but indeed slightly increased rather than decreased, after litter replacement before day 15 of lactation. Replacement after day 17 also did not affect the litter weight gain on the following day, though a definite decrease in the weight gain occurred 2 or 3 days after the replacement. The depression of milk production seems to be due to the effect of estrus which appeared 2 or 3 days after litter replacement in more than a half of animals. Another possibility, worthy of consideration, is that the secretory function of the mammary gland cells become more susceptible to the effect of milk accumulation temporarily resulted from the replacement of suckling pups by the younger ones as the period of lactation was prolonged beyond its normal length. Ill-effects of milk accumulation in the mammary gland on the secretory function of the gland tissue are well established (Ôta, 1964).

The difference in the effect of litter replacement between normal and prolonged lactation lies undoubtedly in the recurrence of the vaginal estrus. After the late stage of normal lactation period, the replacement of pups interrupted the diestrous period very frequently, and, accordingly, the duration of diestrus during the prolonged stage of lactation varied widely in contrast to the uniformity of that of the first diestrus during normal lactation. The results may be ascribed to some changes in the physiological conditions occurring in the mother as the stage of lactation advanced, since the pups used were similar in their age and weight at the time of replacement. Follicular quiescence during lactation may be due to the combined effects of the suckling stimulus and progesterone that suppress the release and/or production of gonadotropins (GTH) in the anterior pituitary gland (Rothchild, 1960; McCann \& Ramirez, 1964; Ford \& Melampy, 1973). We reported in the previous paper (Tomogane et al., 1976) that the concentration of progesterone in the ovarian vein blood of the mother rats was lower during prolonged lactation than during normal lactation. Furthermore, a reduction of the suppressing effect of the suckling stimulus on GTH secretion as lactation advanced was recently confirmed by Ford \& Melampy (1973). Johke (1970) and later Koprowski \& Tucker (1973) on the basis of their results on prolactin secretion in cattle proposed that the sensitivity of the hypothalamus to the milking stimulus decreased as the stage of lactation progressed. The concept may well explain GTH secretion during the prolonged lactation. The depression of the hypothalamic sensitivity to the suckling stimulus associated with the advance of lactation, and the decline in the intensity of the suckling stimulus during prolonged lactation temporarily caused by the replacement of litters, together with the low level of the circulatory progesterone, could relieve the hypothalamic suppression of GTH secretion. GTH, thus secreted, resulted in vaginal estrus.

Despite the decrease in the rate of milk production the daily food consumption of mother rats remained fairly constant after the middle stage of normal lactation. A large difference in feed efficiency between the first 15 days of lactation and the stage from day 30 onwards, when the body 
weights of mother rats increased similarly, implies the occurrence of some alteration of the general maternal metabolism around the end of normal lactation.

\section{Acknowledgements}

We are most grateful to Dr. A. T. Cowie, National Institute for Research in Dairying, England, for reading the manuscript. Our thanks are also due to Mr. R. Ogawa and Mrs. Y. Niwa for their assistance. This work was supported in part by a grant from the Ministry of Education, Japan.

\section{References}

Bruce, H. M. (1961). J. Reprod. Fertil., 2, 17. Ceriotti, G. (1955). J. Biol. Chem., 214, 59.

Dische, Z. \& K. Schwartz (1937). Mikrochim. Acta, 2, 13. cited from Watanabe, K. \& Miura, K. Separation and analysis of nucleic acids and their components, In Zikken Kagaku Koza, Ed. by Jap. Soc. Chem., 23, Biochemistry I, Chap. 2, pp. 243 (1957). (In Japanese)

Ford, J. J. \& R. M. Melampy (1973). Endocrinology, 93, 540.

Johke, T. (1970). Endocrinol. Japon., 17, 393.
Koprowski, J. A. \& H. A. Tucker (1973). Endocrinology, 92, 1480.

Kramer, C. Y. (1956). Biometrics, 12, 307.

Kurz, M. (1967). Symposium on Reproduction, Congr. Hungarian Soc. Endocrinol. \& Metab., p. 175.

Lorscheider, F. L. \& G. J. Mears (1973). J. Endocr., 58, 393.

McCann, S. M. \& V. D. Ramirez (1964). Rec. Progr. Hor. Res., 20, 131.

Nicoll, C. S. \& J. Meites (1959). Proc. Sec. exp. Biol. Med., 101, 81.

Ôta, K. (1964). Endocrinol. Japon., 11, 146.

Ôta, K., Y. Harai, H. Unno, S. Sakauchi, H. Tomogane \& A. Yokoyama (1974). J. Endocr., 62, 679.

Rothchild, I. (1960). Endocrinology, 67, 9.

Schneider, W. C. (1946). J. Biol. Chem., 164, 747.

Thatcher, W. W. \& H. A. Tucker (1968). Proc. Soc. exp. Biol. Med., 128, 46.

Thatcher, W. W. \& H. A. Tucker (1970 a). Ibid., 134, 705.

Thatcher, W. W. \& H. A. Tucker (1970 b). Ibid., 134, 915.

Thatcher, W. W. \& H. A. Tucker $(1970$ c). Endocrinology, 86, 237.

Tomogane, H., K. Ôta \& A. Yokoyama (1976). Endocrinol. Japon., 23, 111.

Yokoi, T. (1967). Thesis for the Master Degree, Faculty of Agriculture, Nagoya University. (In Japanese)

Yokoyama, A., K. Óta \& T. Yokoi (1968). Proceedings of the International Union of Physiological Sciences, $V I, 215$. 